\title{
EARNINGS DIFFERENCES AMONG SENIOR UNIVERSITY ADMINISTRATORS: EVIDENCE BY GENDER AND ACADEMIC FIELD
}

\author{
$\mid \begin{gathered}\text { COLINF. MANG } \\ \text { WILFRID LAURIER UNIVERSITY }\end{gathered}$
}

\begin{abstract}
This study examines earnings inequality by gender and academic field among senior university administrators, including presidents, vice presidents, associate and assistant vice presidents, and deans, using data from the Canadian province of Ontario. While a 4.4 percent earnings gap between male and female administrators is initially identified, much of the gap is explained by earnings inequality across academic fields and by the career experience of the administrators. Administrators who specialize in professional fields such as engineering, health sciences, law, and social work earn between 12 percent and 33 percent more than administrators who specialize in liberal fields in the humanities and social sciences.
\end{abstract}

Keywords: academic executive, compensation, field of study, gender, salary

\section{Résumé}

Cette étude examine les différences de salaire selon le sexe et le domaine de spécialisation chez les cadres supérieurs des universités, y compris les présidents, les vice-présidents, les vice-présidents associés, les vice-présidents adjoints et les doyens, à l'aide de données de la province canadienne de l'Ontario. Si initialement un écart salarial de 4,4 \% est présent entre les administrateurs hommes et femmes, cet écart s'explique en grande partie par l'inégalité des salaires entre les domaines de spécialisation et par l'expérience professionnelle des administrateurs. Les administrateurs spécialisés dans des domaines professionnels tels que l'ingénierie, les sciences de la santé, le droit et le travail social ont des salaires de $12 \%$ à $33 \%$ plus élevés que les administrateurs spécialisés dans les domaines libéraux en sciences humaines et sociales.

Mots-clés : gestionnaire académique, rémunération, domaine d'études, genre, salaire

\section{Introduction}

There has been growing interest in the topic of executive compensation as the wages of executives have, over the past few decades, grown significantly faster than the wages of those they manage, particularly in the United States (e.g. Mishel \& Sabadish, 2013) and Canada (e.g. Mendleson, 2012). However, few studies have examined compensation among senior university administrators, also referred to in the literature as academic executives, i.e. those who manage universities. Furthermore, as most studies of administrator compensation have focused solely on university presidents, little work has been done to assess differences in compensation among administrators below the rank of president. This study examines earnings differences by gender and academic field among administrators throughout the organizational hierarchy.

A large body of literature has examined earnings differences between males and females and has identified productivity related, non-productivity related, and possible discriminatory factors contributing to earnings differences. Given that compensating men and women with equivalent qualifications differently for performing the same job is unethical, identifying whether such practice still occurs in the university sector would be of key public interest.

Studies of university faculty earnings (e.g. Brown, Troutt, \& Prentice, 2011; Ehrenberg, McGraw, \& Mrdjenovic, 2006) have shown that those in professional disciplines, (for example business, engineering, and law), 
earn significantly more than those in liberal disciplines in the humanities and social sciences. However, whether earnings differentials by academic field among faculty translate into earnings differentials among already highly compensated administrators has not been thoroughly explored in the literature to date.

The literature examining compensation for university administrators is small and focused primarily on the earnings of university presidents / vice-chancellors. While a few studies such as Clements and Izan (2008) and Essaji and Horton (2010) have examined compensation of administrators below the rank of president, Monks and McGoldrick (2004) is the only study thus far to focus on the gender earnings gap among administrators; however, that study does not consider individual characteristics such as academic field which could affect earnings, leading to a biased estimate of the earnings gap. There is thus significant opportunity to expand the literature examining administrator compensation by considering gender and academic field differentials throughout the hierarchy of university administration.

The following section provides a review of the literature. Next, a framework is developed to model administrator earnings and assess earnings differentials. The model is tested using data from the Canadian province of Ontario for the years 2000-2011. Ontario universities compete in a continent-wide market for university administrators and numerous individuals in the sample have worked in multiple US states and/or Canadian provinces; therefore, compensation would be expected to be competitive and comparable with other jurisdictions given institutional characteristics such as size and reputation. However, unlike other jurisdictions where salary data is limited, Ontario law requires all institutions to publish nearly all salary records, thus providing for a much larger sample than the samples used in previous studies, and also avoiding the possibility of bias which previous studies had to contend with given that their data was drawn from non-random subsets of institutions which chose to make data available, rather than from all institutions in a jurisdiction. The study concludes with a discussion of the findings.

\section{Literature Review}

\section{Salaries of University Administrators}

The literature examining the earnings of university administrators is small, and nearly all studies have focused exclusively on university presidents/vice-chancellors. The only studies to examine compensation among lower ranks of administrators have been: Clements and Izan (2008) for the five highest paid administrators (positions undetermined) at Australian universities; Essaji and Horton (2010) for presidents, vice presidents, and deans at Canadian universities; Monks and McGoldrick (2004) for presidents, vice presidents, program directors, and deans at American private universities; and Pfeffer and Davis-Blake (1987) for the heads of development, admissions, business functions, alumni affairs, community services, student placement, athletics, and public relations at American universities. With only two studies examining the earnings of deans and no studies examining the earnings of associate vice presidents and assistant vice presidents, there is significant opportunity to expand the literature in this area.

Some studies (Clements \& Izan, 2008; Soh, 2007; Tang, Tang, \& Tang, 2000) have modeled earnings solely based on institutional characteristics; however, as gender and career background have been shown to affect compensation of executives generally (e.g. Gayle, Golan, \& Miller, 2012) and university administrator compensation in particular (e.g. Bartlett \& Sorokina, 2005), personal characteristics should be included in any analysis of administrator earnings.

\section{Male-Female Earnings Differentials}

A very large literature has explored the male-female earnings gap. Reviews are provided by Blau, Ferber, and Winkler (2002), Blau and Kahn (2000), Holzer and Neumark (2000), and Gunderson (2006) among others. Numerous studies have identified productivity related factors such as differences in educational background (Chevalier, 2007; Drolet, 2002b; Livanos \& Pouliakas, 2012; Napari, 2011) and firm size (Bertrand \& Hallock, 2001; Drolet, 2002a) as determinants of the earnings gap, while some studies, after accounting for a range of observable characteristics, have attributed the remaining earnings gap to overt discrimination against females 
(e.g. Goldin \& Rouse, 2000; Gunderson, 1989; Holzer \& Neumark, 2000; Jarrell \& Stanley, 2004). Gender-role stereotyping has been identified as a factor contributing to females choosing particular fields of study and particular professions (Bailey, 1992; Purcell, Elias, Davies, \& Wilton, 2005; U.S. Department of Education, 2001) and these "feminized" professions (i.e. female-dominated), have experienced lower earnings that male-dominated professions, thus contributing to the earnings gap (see Drewes, 2006; Hansen, 2006; Greenman \& Xie, 2008; McCormick, Nunez, Shah, \& Choy, 1999; Purcell et al., 2005).

As well, non-productivity related explanations of the gender earnings gap have been proposed including differing attitudes towards competitiveness (Flory, Leibbrandt, \& List, 2014; Gneezy, Niederle, \& Rustichini, 2003; Niederle \& Vesterlund, 2007), differing attitudes towards risk (Eckel \& Grossman, 2002; Le, Miller, Slutske, \& Martin, 2011; Powell \& Ansic, 1997; Schubert, Brown, Gysler, \& Brachinger, 1999), and differing earnings expectations (Furnham \& Wilson, 2011; Need \& De Jong, 2008; Williams, Paluck, \& Spencer-Rogers, 2010) which may lead females to accept lower pay offers. Babcock, Gelfand, Small, and Stayn (2006), Babcock and Laschever (2003), and Small et al. (2007) all show that males are more likely than females to bargain for higher salaries.

Other than Monks and McGoldrick (2004), examination of the gender earnings gap has not been a primary focus of the literature examining university administrator compensation. Nevertheless, several American studies have included gender, with Pfeffer and Ross (1988) and Ehrenberg, Cheslock, and Epifantseva (2001) identifying instances in which male university presidents out-earned comparable female presidents by seven percent to ten percent and by three percent to six percent respectively; however, Bartlett and Sorokina (2005) and Ehrenberg, Cheslock, and Epifantseva (2001) have also found that female presidents of liberal arts colleges out-earned comparable male presidents by nine percent and by three and a half percent respectively, while Monks (2007), Langbert and Fox (2013), and Huang and Chen (2013) do not find evidence of a gender earnings gap among university presidents. The range of these findings likely resulted from the samples employed as each study used data from non-random samplings of institutions drawn from niche subsets of the very large American college market, making comparisons between the studies diffi- cult due to the heterogeneity of the institutions examined. Monks and McGoldrick (2004) and Essaji and Horton (2010), examined administrators below the rank of president and found that females earned between four and thirteen percent less than their male counterparts; however, neither study examined any personal characteristics of the administrators such as academic field and academic rank which have been shown to affect the compensation of university presidents / vice-chancellors (e.g. Baimbridge \& Simpson, 1996; Monks, 2007), which undoubtedly biases their estimates of the gender earnings gap given differences in the distribution of males and females across academic fields (Binder, Krause, Chermak, Thacher, \& Gilroy, 2010; Brown, Troutt, \& Prentice, 2011; Warman, Woolley, \& Worswick, 2010) and academic ranks (Ginther \& Hayes, 2003; Mcdowell \& Smith, 1992; Ornstein, Steward, \& Drakich, 2007; Wijesingha \& Ramos, 2017). Therefore, there is a significant opportunity to explore the male-female earnings differential among university administrators throughout the executive hierarchy.

\section{Earnings and Academic Field}

A large body of literature has explored differences in graduate earnings across academic fields with numerous studies identifying higher earnings among graduates of professional programs such as business and engineering compared to graduates of liberal programs in the humanities, social sciences, and sciences (e.g. Altonji, Blom, \& Meghir, 2012; Boothby \& Drewes, 2006; Chia $\&$ Miller, 2008). Jalbert, Furumo, and Jalbert (2011) and Palia (2000) specifically show that academic field can affect executive compensation and position within private sector organizations.

Within universities, numerous studies have shown that faculty specializing in professional fields such as business, engineering, law, and medicine earn more than faculty specializing in education, humanities, social sciences, or sciences (e.g. Brown, Troutt, \& Prentice, 2011; Doucet, Durand, \& Smith, 2008; Ehrenberg et al., 2006; Warman et al., 2010) while Binder et al. (2010) show that these differences contribute to an earnings differential between male and female faculty members as higher paying fields have a higher proportion of male faculty members. However, an examination of academic field is not commonly considered in studies of administrator compensation. Baimbridge and Simpson (1996) find that 
UK vice-chancellors who specialized in science earned 4.5 percent more than those who specialized in engineering and twelve percent more than those who specialized in humanities or social sciences. Bartlett and Sorokina (2005) examine whether presidents of American liberal arts colleges who specialized in business, economics, or law earn more than presidents from other fields, but their estimated premiums of four percent for salary and two percent for total compensation including non-salary benefits are not statistically significant. Monks (2007) found that presidents of American private universities who specialized in sciences earned eleven percent more than those who specialized in social sciences, but could not find statistically significant differences in earnings among other fields at either private or public institutions, possibly because of the very small sample sizes employed $(n=67$ for public universities and $n=49$ for private universities).

The existing literature examining the effect of academic field on the earnings of universities presidents is limited, and although Essaji and Horton (2010) provide some measure of differentiation by separating deans of business, engineering, and health sciences from other deans, there is a substantial gap in the literature as the impact of academic field on the earnings of university vice presidents, associate vice presidents and assistant vice presidents, and deans has not previously been explored.

\section{Methodology}

As in previous studies, the natural log of a university administrator's total compensation including both salary and benefits, expressed in constant year 2000 dollars, is modeled in Equation 1 as a function of the administrator's gender, academic field, position, and career background including academic rank (if any), years in their current position, and estimated years of professional work experience, which is calculated as in Binder et al. (2010) by examining the time since the completion of the individual's highest university degree ${ }^{1}$.

As in Monks (2007), Langbert and Fox (2013), and Pfeffer and Ross (1988), whether an administrator is hired externally or promoted internally is also considered, as those hired externally have greater bargaining power in salary negotiation since they may require a wage premium to change organizations, and are being offered the position over - and are therefore more desirable than any internal candidates (if any). In contrast, internal hires may be willing to accept a wage penalty for the convenience of obtaining a more senior position without having to change institutions. Examining the premium obtained by external hires and comparing the outcomes for males and females should also contribute to understanding whether males and females experience different bargaining conditions / outcomes.

The size of each institution is measured by its (log) revenues in year 2000 constant dollars (see Clements \& Izan, 2008; Huang \& Chen, 2013; and Soh, 2007). The annual Macleans university rankings, which Cyrenne and Grant (2009) show to be a good proxy for institutional quality, are included to account for the impact on earnings of both relative quality among the institutions and changes in relative quality over time. As not all universities appear in the rankings each year, unranked institutions are assigned the next value below the lowest ranked institution as in Monks and Ehrenberg (1999). As several institutions in the sample operate subsidiaries/ secondary campuses, or have federated structures with affiliated universities/colleges, whether an administrator works within one of these subordinate organizations is included as a control. Finally, as Essaji and Horton (2010) have shown that salaries have been rising in real terms over time, a series of Time Effects is included to account for sector-wide changes in earnings.

In(Total Compensation)

(1)

$$
\begin{aligned}
& =\beta_{0}+\beta_{F} \text { Female }+\beta_{A} \text { Academic Field }+\beta_{C} \text { Career Background } \\
& +\beta_{P} \text { Position }+\beta_{I} \text { Institutional Controls }+\beta_{T} \text { Time Effects }+\varepsilon
\end{aligned}
$$

As there is no standard list of job titles corresponding to the responsibilities of university administrators that are common to all institutions, this study uses a framework similar to that proposed by Essaji and Horton (2010) for establishing equivalency between various job titles for comparison purposes. The list of job titles considered to be equivalent is presented in Table 1 . Given the wide range of decanal positions, aggregation among deans for some professional programs and for some liberal programs is necessary. As an individual's academic field will be considered, assigning deans to these categories will only identify any "extra" wage premium that comes from being the dean of a particular professional faculty relative to being a dean in a liberal faculty; i.e. combining a dean of law with a dean of social work is not detrimental, even if higher wages are paid to law specialists than to social work specialists, because the returns to academic field would account for the difference. Similarly, combining a dean of science with a 
dean of arts also does not pose identification problems so long as academic field is also considered.

Similar to Essaji and Horton (2010) and Monks and McGoldrick (2004), this study considers the total compensation for presidents, vice presidents, and deans. In addition, this study considers associate vice presidents and assistant vice presidents which have not previously been examined in the literature. in nominal terms since 1996, which may create some bias in the data in the earliest years as some of the mid-level executives, such as deans and assistant vice presidents did not reach the earnings threshold. However, that problem affected all institutions, and as nominal wages rose throughout the sector, more individuals were captured at every institution. To compensate for this problem, this study uses only data from the year 2000 onward when

Table 1. List of Job Title Equivalencies by Position Category

\begin{tabular}{|c|c|}
\hline Title & Alternative Equivalent Titles \\
\hline President & President and Vice-Chancellor, Principal and Vice-Chancellor, Principal \\
\hline Vice President Academic & $\begin{array}{l}\text { Provost, Vice President Academic Affairs, Vice President Academic and Provost, Vice } \\
\text { President Academic and Research, Vice Principal Academic, Vice Principal Academic and } \\
\text { Provost }\end{array}$ \\
\hline Vice President Administration & $\begin{array}{l}\text { Vice President Administration and Finance, Vice President Administration and Student } \\
\text { Affairs, Vice President Finance, Vice President Finance and Administration, Vice President } \\
\text { Operations and Finance, Vice President Planning and Administration, Vice Principal Opera- } \\
\text { tions and Finance }\end{array}$ \\
\hline Vice President External & $\begin{array}{l}\text { Vice President Advancement, Vice President Alumni Affairs and Development, Vice Pres- } \\
\text { ident Development and Public Affairs, Vice President External Relations, Vice President } \\
\text { University Advancement, Vice President University Affairs, Vice Principal Advancement }\end{array}$ \\
\hline Vice President Research & $\begin{array}{l}\text { Vice President Research and Development, Vice President Research and International } \\
\text { Affairs, Vice President University Research, Vice Principal Research }\end{array}$ \\
\hline Other Vice President & $\begin{array}{l}\text { Includes all other Vice Presidents such as Vice President of Business Affairs, Vice Pres- } \\
\text { ident of Human Resources, Vice President of Strategic Initiatives, Vice President of } \\
\text { Students, etc. }\end{array}$ \\
\hline Associate Vice President & Associate Provost, Associate Vice Principal, Deputy Provost, Vice Provost \\
\hline Assistant Vice President & - \\
\hline Dean of Business & Dean of Management \\
\hline Dean of Engineering & Dean of Science and Engineering \\
\hline Dean of Health Sciences & Dean of Medicine, Dean of Dentistry, Dean of Pharmacy \\
\hline Dean of Professional Faculty & $\begin{array}{l}\text { Dean of Agriculture, Dean of Applied Health Sciences, Dean of Law, Dean of Nursing, Dean } \\
\text { of Social Work, Dean of Veterinary Medicine }\end{array}$ \\
\hline Dean of Liberal Faculty & $\begin{array}{l}\text { Dean of Arts, Dean of Arts and Sciences, Dean of Education, Dean of Fine Arts, Dean of } \\
\text { Graduate Studies, Dean of Humanities, Dean of Sciences, Dean of Social Sciences }\end{array}$ \\
\hline
\end{tabular}

\section{Data}

Earnings data are drawn from the Public Sector Salary Disclosure files of the Ontario Ministry of Finance which reports the total salary and taxable benefits of each university employee whose combined salary and benefits total more than $\$ 100,000$. The $\$ 100,000$ limit has been fixed salaries were sufficiently high for effectively all administrators to be captured. As earnings data is provided for each tax year, from January 1st to December 31st, any observations from an administrator who did not remain in a position for the full calendar year are excluded. Earnings data are supplemented with biographical information 
gathered from university and personal websites, library archives, department records, curricula vitae, Linkedln profiles, public records, and direct contacts.

Of the 836 administrators in the database, detailed background information was obtainable for 711 ( 85 percent). Two assistant professors, one female and one male representing four observations in total were removed due to a lack of comparators. The remaining 709 administrators yielded a total sample size of 3190 observations over twelve years. Table 2 describes the features of the 709 administrators examined by academic field, career background, and position held. Of the 487 male administrators examined, 363 succeeded another male administrator upon taking up the position, 68 succeeded a female administrator, and 56 were the initial holders of newly created positions. Of the 222 female administrators examined, 130 succeeded a male administrator upon taking up the position, 45 succeeded another female administrator, and 47 were the initial holders of newly created positions.

Table 2. Characteristics of the Senior University Administrators, 2000-2011

\begin{tabular}{|c|c|c|c|c|}
\hline & \multicolumn{2}{|c|}{$\begin{array}{l}\text { Number of University } \\
\text { Administrators } \\
\end{array}$} & \multirow[t]{2}{*}{ Number of Observations } & \multirow[t]{2}{*}{$\begin{array}{l}\text { Average Earnings (Year } \\
2000 \text { Constant \$) }\end{array}$} \\
\hline & Male & Female & & \\
\hline Total & 487 & 222 & 3190 & 164,894 \\
\hline
\end{tabular}

Academic Field

Business

Economics

Education

Engineering

Humanities

Law

Health sciences

Nursing

Sciences

Social sciences

Social work

\section{Career Background}

Professor

386

131

2378

Associate Professor

33

68

22

177

Not an academic

Position ${ }^{\mathrm{a}}$

President

Vice President Academic

Vice President Administration

Vice President External

Vice President Research
68

43

15

17

30
69

635
168,050

127,882

166,236

173,906

158,606

183,749

148,641

199,016

258,394

151,889

158,227

155,260

152,309

163,388 


\begin{tabular}{|c|c|c|c|c|}
\hline & \multicolumn{2}{|c|}{$\begin{array}{l}\text { Number of University } \\
\text { Administrators }\end{array}$} & \multirow[t]{2}{*}{ Number of Observations } & \multirow[t]{2}{*}{$\begin{array}{l}\text { Average Earnings (Year } \\
2000 \text { Constant \$) }\end{array}$} \\
\hline & Male & Female & & \\
\hline Vice President Other & 13 & 5 & 62 & 216,541 \\
\hline Associate Vice President & 95 & 56 & 583 & 139,287 \\
\hline Assistant Vice President & 29 & 25 & 196 & 138,576 \\
\hline Dean of Business & 21 & 7 & 141 & 196,640 \\
\hline Dean of Engineering & 27 & 3 & 138 & 160,861 \\
\hline Dean of Health Sciences & 9 & 3 & 68 & 244,787 \\
\hline Dean of Professional Faculty & 27 & 20 & 187 & 158,007 \\
\hline Dean of Liberal Faculty & 161 & 66 & 849 & 135,772 \\
\hline
\end{tabular}

${ }^{a}$ Figures for number of administrators by position do not sum to total number of administrators listed above because some administrators changed position and therefore provide observations in more than one position category.

\section{Analysis of Academic Executive Salaries}

Various specifications of Equation 1 are estimated using the Stata software package, with standard errors clustered by individual university administrator. The results are reported in Columns I through IV of Table 3. The reference case or constant term (intercept of the equation) is the log earnings of a dean of a liberal faculty member who is male (Columns I, II, III, IV), a specialist in a humanities field (Columns II, IV, V, VI), has had a career in the academy (Columns II, II) has obtained the rank of professor (Columns III, IV, V, VI), and who has been promoted internally (Columns III, IV, V, VI). The coefficients listed in the table represent the estimated difference in log earnings between an individual in the reference case and an individual with a different characteristic. Most of the variability in earnings is accounted for by executive position, institutional characteristics, and time; however, the inclusion of educational background and career background in Columns II, III, and IV respectively provide insights into the gender earnings disparity identified in Column I. Columns V and VI estimate the model separately for males and females respectively. Column VII reports the results of a Hausman chi-squared test of the difference between coefficients in the male and female model specifications; the test is conducted using the Stata suest function.

Female administrators are shown to earn about 4.4 percent less on average than male colleagues after ac- counting for position, institutional characteristics, and whether the individual pursued a career in the academy or is a professional administrator. However, this gap is largely explained by earnings differences across academic fields, and by career background. After accounting for these characteristics, the earnings gap is only 2.6 percent and is not statistically significant. Administrators with a background in health science earn substantially more than all other administrators, while those in business, engineering, law, nursing, and social work earn premiums of between 5.5 and 15.5 percent over administrators with backgrounds in humanities, sciences, and social sciences.

Each additional year of work experience increases an administrator's earnings by 0.3 percent in real terms, while each additional year spent in the same position brings a further 1.2 percent real increase in earnings. External hires receive on average 9.1 percent more than those promoted internally.

Given the great degree of heterogeneity in job tasks performed by associate vice presidents and assistant vice presidents, and in particular the question of whether associate/assistant vice presidents coming from a career in the academy are comparable to those with a professional administrative background, the analysis is run separately for this group of administrators and the results for academics and professional administrators are compared using the method described above. The results reported in the Appendix show that the groups are comparable. No statistically significant differences among males and females across these groups are found, nor are the returns to academic field shown to be different, 
with the exception of engineering professors/associate professors who earn a premium over professional engineers. The only significant difference between associate/assistant vice presidents with an academic career and those without is a premium paid to external hires coming from a career in the academy.

Table 4 extends the analysis to examine what impact the gender of an administrator's predecessor, if any, contributes to an earnings differential among male and female administrators. Results are reported relative to male administrators who are the initial holder of a newly created position. The difference in earnings between a male administrator who succeeded another male and a male administrator in a newly created position is not statistically significant, nor is the difference in earnings between a male administrator who succeeded a female and a male administrator in a newly created position statistically significant. Likewise, the difference in earnings between a female administrator who succeeded a male and a male administrator in a newly created position is not statistically significant. However, the earnings of a female administrator who succeeded another female and the earnings of a female administrator in a newly created position are 6.8 percent and 7.0 percent lower than the earnings of a male administrator in a newly created position respectively.

Table 3. Determinants of Senior University Administrator Earnings ${ }^{b}$

\begin{tabular}{|c|c|c|c|c|c|c|c|}
\hline & I & II & III & IV & V & VI & VII \\
\hline & Full Sample & Full Sample & Full Sample & Full Sample & Males & Females & $\chi^{2}$-test of male-female differences \\
\hline Female & $\begin{array}{l}-0.045^{* * *} \\
(0.016)\end{array}$ & $\begin{array}{l}-0.039^{* *} \\
(0.016)\end{array}$ & $\begin{array}{l}-0.032^{* *} \\
(0.016)\end{array}$ & $\begin{array}{l}-0.027 \\
(0.016)\end{array}$ & & & \\
\hline Business & & $\begin{array}{l}0.056^{* *} \\
(0.027)\end{array}$ & & $\begin{array}{l}0.054^{* *} \\
(0.027)\end{array}$ & $\begin{array}{l}0.071^{*} \\
(0.039)\end{array}$ & $\begin{array}{l}0.047 \\
(0.034)\end{array}$ & 0.21 \\
\hline Economics & & $\begin{array}{l}0.017 \\
(0.049)\end{array}$ & & $\begin{array}{l}0.004 \\
(0.042)\end{array}$ & $\begin{array}{l}0.007 \\
(0.046)\end{array}$ & $\begin{array}{l}0.040 \\
(0.065)\end{array}$ & 0.18 \\
\hline Education & & $\begin{array}{l}0.059 \\
(0.038)\end{array}$ & & $\begin{array}{l}0.039 \\
(0.035)\end{array}$ & $\begin{array}{l}0.051 \\
(0.047)\end{array}$ & $\begin{array}{l}0.011 \\
(0.050)\end{array}$ & 0.34 \\
\hline Engineering & & $\begin{array}{l}0.139^{* * *} \\
(0.028)\end{array}$ & & $\begin{array}{l}0.139^{* * *} \\
(0.028)\end{array}$ & $\begin{array}{l}0.149^{* * *} \\
(0.031)\end{array}$ & $\begin{array}{l}0.157^{* *} \\
(0.063)\end{array}$ & 0.01 \\
\hline Law & & $\begin{array}{l}0.145^{* * *} \\
(0.038)\end{array}$ & & $\begin{array}{l}0.144^{* * *} \\
(0.039)\end{array}$ & $\begin{array}{l}0.157^{* * *} \\
(0.050)\end{array}$ & $\begin{array}{l}0.156^{* *} \\
(0.075)\end{array}$ & 0.00 \\
\hline Health science & & $\begin{array}{l}0.271^{* * *} \\
(0.061)\end{array}$ & & $\begin{array}{l}0.288^{* * *} \\
(0.066)\end{array}$ & $\begin{array}{l}0.346^{* * *} \\
(0.067)\end{array}$ & $\begin{array}{l}0.049 \\
(0.167)\end{array}$ & $2.86^{*}$ \\
\hline Nursing & & $\begin{array}{l}0.090 \\
(0.065)\end{array}$ & & $\begin{array}{l}0.109^{*} \\
(0.063)\end{array}$ & $\begin{array}{l}0.358^{* * *} \\
(0.037)\end{array}$ & $\begin{array}{l}0.061 \\
(0.065)\end{array}$ & $16.27^{* * *}$ \\
\hline Sciences & & $\begin{array}{l}0.034 \\
(0.021)\end{array}$ & & $\begin{array}{l}0.032 \\
(0.020)\end{array}$ & $\begin{array}{l}0.047^{* *} \\
(0.024)\end{array}$ & $\begin{array}{l}-0.017 \\
(0.036)\end{array}$ & 2.40 \\
\hline Social science & & $\begin{array}{l}0.015 \\
(0.023)\end{array}$ & & $\begin{array}{l}0.013 \\
(0.021)\end{array}$ & $\begin{array}{l}0.016 \\
(0.024)\end{array}$ & $\begin{array}{l}0.008 \\
(0.039)\end{array}$ & 0.03 \\
\hline
\end{tabular}




\begin{tabular}{|c|c|c|c|c|c|c|c|}
\hline & 1 & II & III & IV & $\mathrm{v}$ & $\mathrm{VI}$ & VII \\
\hline & Full Sample & Full Sample & Full Sample & Full Sample & Males & Females & $\chi^{2}$-test of male-female differences \\
\hline Social work & & $\begin{array}{l}0.095^{* * *} \\
(0.036)\end{array}$ & & $\begin{array}{l}0.120^{* * *} \\
(0.034)\end{array}$ & $\begin{array}{l}0.180^{* * *} \\
(0.066)\end{array}$ & $\begin{array}{l}0.075^{* *} \\
(0.038)\end{array}$ & 1.94 \\
\hline Experience (years) & & & $\begin{array}{l}0.003^{* * *} \\
(0.001)\end{array}$ & $\begin{array}{l}0.003^{* * *} \\
(0.001)\end{array}$ & $\begin{array}{l}0.003^{* *} \\
(0.001)\end{array}$ & $\begin{array}{l}0.005^{* * *} \\
(0.002)\end{array}$ & 1.37 \\
\hline Position Tenure (years) & & & $\begin{array}{l}0.011^{* * *} \\
(0.002)\end{array}$ & $\begin{array}{l}0.012^{* * *} \\
(0.002)\end{array}$ & $\begin{array}{l}0.013^{* * *} \\
(0.003)\end{array}$ & $\begin{array}{l}0.007^{*} \\
(0.003)\end{array}$ & 2.23 \\
\hline Associate Professor & & & $\begin{array}{l}-0.076^{* * *} \\
(0.026)\end{array}$ & $\begin{array}{l}-0.075^{* * *} \\
(0.022)\end{array}$ & $\begin{array}{l}-0.107^{* * *} \\
(0.028)\end{array}$ & $\begin{array}{l}-0.021 \\
(0.038)\end{array}$ & 3.51 \\
\hline External Hire & & & $\begin{array}{l}0.084^{* * *} \\
(0.016)\end{array}$ & $\begin{array}{l}0.087^{* * *} \\
(0.016)\end{array}$ & $\begin{array}{l}0.095^{* * *} \\
(0.020)\end{array}$ & $\begin{array}{l}0.080^{* * *} \\
(0.025)\end{array}$ & 0.22 \\
\hline Professional Administrator $^{\mathrm{C}}$ & $\begin{array}{l}-0.067^{* *} \\
(0.028)\end{array}$ & $\begin{array}{l}-0.063^{* *} \\
(0.030)\end{array}$ & $\begin{array}{l}-0.098^{* * *} \\
(0.028)\end{array}$ & $\begin{array}{l}-0.093^{* * *} \\
(0.030)\end{array}$ & $\begin{array}{l}-0.118^{* * *} \\
(0.041)\end{array}$ & $\begin{array}{l}-0.095^{* *} \\
(0.043)\end{array}$ & 0.16 \\
\hline President & $\begin{array}{l}0.586^{* * *} \\
(0.032)\end{array}$ & $\begin{array}{l}0.556^{* * *} \\
(0.032)\end{array}$ & $\begin{array}{l}0.533^{* * *} \\
(0.031)\end{array}$ & $\begin{array}{l}0.500^{* * *} \\
(0.030)\end{array}$ & $\begin{array}{l}0.493^{* * *} \\
(0.035)\end{array}$ & $\begin{array}{l}0.517^{* * *} \\
(0.063)\end{array}$ & 0.12 \\
\hline VPAcademic & $\begin{array}{l}0.309^{* * *} \\
(0.025)\end{array}$ & $\begin{array}{l}0.286^{* * *} \\
(0.024)\end{array}$ & $\begin{array}{l}0.304^{* * *} \\
(0.025)\end{array}$ & $\begin{array}{l}0.281^{* * *} \\
(0.022)\end{array}$ & $\begin{array}{l}0.272^{* * *} \\
(0.024)\end{array}$ & $\begin{array}{l}0.314^{* * *} \\
(0.042)\end{array}$ & 0.82 \\
\hline VPAdmin & $\begin{array}{l}0.323^{* * *} \\
(0.034)\end{array}$ & $\begin{array}{l}0.290^{* * *} \\
(0.032)\end{array}$ & $\begin{array}{l}0.267^{* * *} \\
(0.040)\end{array}$ & $\begin{array}{l}0.229^{* * *} \\
(0.038)\end{array}$ & $\begin{array}{l}0.262^{* * *} \\
(0.050)\end{array}$ & $\begin{array}{l}0.220^{* * *} \\
(0.049)\end{array}$ & 0.37 \\
\hline VP External & $\begin{array}{l}0.420^{* * *} \\
(0.057)\end{array}$ & $\begin{array}{l}0.387^{* * *} \\
(0.055)\end{array}$ & $\begin{array}{l}0.398^{* * *} \\
(0.053)\end{array}$ & $\begin{array}{l}0.362^{* * *} \\
(0.051)\end{array}$ & $\begin{array}{l}0.401^{* * *} \\
(0.065)\end{array}$ & $\begin{array}{l}0.299^{* * *} \\
(0.080)\end{array}$ & 1.00 \\
\hline VP Research & $\begin{array}{l}0.196^{* * *} \\
(0.029)\end{array}$ & $\begin{array}{l}0.142^{* * *} \\
(0.031)\end{array}$ & $\begin{array}{l}0.202^{* * *} \\
(0.026)\end{array}$ & $\begin{array}{l}0.147^{* * *} \\
(0.029)\end{array}$ & $\begin{array}{l}0.117^{* * *} \\
(0.036)\end{array}$ & $\begin{array}{l}0.249^{* * *} \\
(0.037)\end{array}$ & $6.76^{* * *}$ \\
\hline Other VP & $\begin{array}{l}0.316^{* * *} \\
(0.079)\end{array}$ & $\begin{array}{l}0.237^{* * *} \\
(0.052)\end{array}$ & $\begin{array}{l}0.322^{* * *} \\
(0.078)\end{array}$ & $\begin{array}{l}0.240^{* * *} \\
(0.053)\end{array}$ & $\begin{array}{l}0.170^{* *} \\
(0.066)\end{array}$ & $\begin{array}{l}0.303^{* * *} \\
(0.047)\end{array}$ & $2.77^{*}$ \\
\hline Associate VP & $\begin{array}{l}-0.049^{* *} \\
(0.021)\end{array}$ & $\begin{array}{l}-0.070^{* * *} \\
(0.021)\end{array}$ & $\begin{array}{l}-0.021 \\
(0.019)\end{array}$ & $\begin{array}{l}-0.042^{* *} \\
(0.019)\end{array}$ & $\begin{array}{l}-0.044^{* *} \\
(0.021)\end{array}$ & $\begin{array}{l}-0.038 \\
(0.039)\end{array}$ & 0.02 \\
\hline Assistant VP & $\begin{array}{l}-0.026 \\
(0.035)\end{array}$ & $\begin{array}{l}-0.055 \\
(0.035)\end{array}$ & $\begin{array}{l}-0.027 \\
(0.033)\end{array}$ & $\begin{array}{l}-0.058^{*} \\
(0.034)\end{array}$ & $\begin{array}{l}-0.045 \\
(0.044)\end{array}$ & $\begin{array}{l}-0.070 \\
(0.051)\end{array}$ & 0.14 \\
\hline Dean of business & $\begin{array}{l}0.297^{* * *} \\
(0.062)\end{array}$ & $\begin{array}{l}0.275^{* * *} \\
(0.063)\end{array}$ & $\begin{array}{l}0.256^{* * *} \\
(0.054)\end{array}$ & $\begin{array}{l}0.233^{* * *} \\
(0.056)\end{array}$ & $\begin{array}{l}0.200^{* * *} \\
(0.059)\end{array}$ & $\begin{array}{l}0.308^{* *} \\
(0.132)\end{array}$ & 0.58 \\
\hline
\end{tabular}




\begin{tabular}{|c|c|c|c|c|c|c|c|}
\hline & I & II & III & IV & V & $\mathrm{VI}$ & VII \\
\hline & Full Sample & Full Sample & Full Sample & Full Sample & Males & Females & $\chi^{2}$-test of male-female differences \\
\hline Dean of engineering & $\begin{array}{l}0.102^{* * *} \\
(0.037)\end{array}$ & $\begin{array}{l}-0.001 \\
(0.041)\end{array}$ & $\begin{array}{l}0.099^{* * *} \\
(0.034)\end{array}$ & $\begin{array}{l}-0.007 \\
(0.038)\end{array}$ & $\begin{array}{l}-0.034 \\
(0.039)\end{array}$ & $\begin{array}{l}0.119 \\
(0.138)\end{array}$ & 1.22 \\
\hline Dean of health sciences & $\begin{array}{l}0.430^{* * *} \\
(0.083)\end{array}$ & $\begin{array}{l}0.237^{* * *} \\
(0.080)\end{array}$ & $\begin{array}{l}0.398^{* * *} \\
(0.083)\end{array}$ & $\begin{array}{l}0.189^{* *} \\
(0.080)\end{array}$ & $\begin{array}{l}0.116 \\
(0.088)\end{array}$ & $\begin{array}{l}0.474^{* *} \\
(0.189)\end{array}$ & $3.09^{*}$ \\
\hline Dean of professional faculty & $\begin{array}{l}0.075^{* *} \\
(0.032)\end{array}$ & $\begin{array}{l}0.018 \\
(0.034)\end{array}$ & $\begin{array}{l}0.068^{* *} \\
(0.032)\end{array}$ & $\begin{array}{l}0.006 \\
(0.032)\end{array}$ & $\begin{array}{l}-0.022 \\
(0.044)\end{array}$ & $\begin{array}{l}0.046 \\
(0.049)\end{array}$ & 1.09 \\
\hline Revenue (log) & $\begin{array}{l}0.086^{* * *} \\
(0.012)\end{array}$ & $\begin{array}{l}0.083^{* * *} \\
(0.012)\end{array}$ & $\begin{array}{l}0.086^{* * *} \\
(0.011)\end{array}$ & $\begin{array}{l}0.083^{* * *} \\
(0.011)\end{array}$ & $\begin{array}{l}0.071^{* * *} \\
(0.012)\end{array}$ & $\begin{array}{l}0.115^{* * *} \\
(0.019)\end{array}$ & $4.04^{* *}$ \\
\hline Institutional Characteristics & Included & Included & Included & Included & Included & Included & \\
\hline Time Effects & Included & Included & Included & Included & Included & Included & \\
\hline Reference Case (Constant) ${ }^{d}$ & $\begin{array}{l}10.663^{* * *} \\
(0.162)\end{array}$ & $\begin{array}{l}10.673^{* * *} \\
(0.159)\end{array}$ & $\begin{array}{l}10.520^{* * *} \\
(0.148)\end{array}$ & $\begin{array}{l}10.529^{* * *} \\
(0.143)\end{array}$ & $\begin{array}{l}10.699^{* * *} \\
(0.165)\end{array}$ & $\begin{array}{l}10.024^{* * *} \\
(0.258)\end{array}$ & $5.06^{* *}$ \\
\hline Observations & 3190 & 3190 & 3190 & 3190 & 2244 & 946 & \\
\hline Clusters & 709 & 709 & 709 & 709 & 487 & 222 & \\
\hline$R^{2}$ & 0.631 & 0.656 & 0.669 & 0.696 & 0.712 & 0.704 & \\
\hline
\end{tabular}

b - Standard errors clustered by individual academic executive reported in brackets.

c - Refers to an individual who did not pursue a career in the academy (i.e. has not previously held a tenured / tenure-track position)

$d$ - Reference case represents the log salary for an individual with the following characteristics when all continuous variables in Equation 1 are set at zero (i.e. the constant term in Equation 1 ).

Column I: A male dean of a liberal faculty who also holds an academic (tenured/tenure-track) appointment

Column II: A male dean of a liberal faculty with an academic specialization in the humanities who holds an academic (tenured/tenure-track) appointment

Column III: A male dean of a liberal faculty who holds an academic appointment as a professor and who is promoted internally

Column IV: A male dean of a liberal faculty with an academic specialization in the humanities who holds an academic appointment as a professor and who is promoted internally

Column V and VI: A dean of a liberal faculty with an academic specialization in the humanities who holds an academic appointment as a professor and who is promoted internally

${ }^{*} p<0.1$

${ }^{* *} p<0.5$

${ }^{* * *} p<0.01$ 
Table 4. Log Earnings Differences by Administrator Gender and Gender of Predecessor Relative to Male Administrators with No Predecessor

\begin{tabular}{ll}
\hline Male Administrator / Male Predecessor & -0.029 \\
& $(0.024)$ \\
Male Administrator / Female Predecessor & 0.005 \\
& $(0.033)$ \\
Female Administrator / Male Predecessor & -0.035 \\
& $(0.028)$ \\
Female Administrator / Female Predecessor & $-0.070^{*}$ \\
& $(0.036)$ \\
Female Administrator / No Predecessor & $-0.073^{* *}$ \\
& $(0.033)$ \\
Academic Field & Included \\
Career Background & Included \\
Position & Included \\
Institutional Characteristics & Included \\
Time Effects & Included \\
Observations & \\
Clusters & 3190 \\
$R^{2}$ & 709 \\
\hline
\end{tabular}

${ }^{*} p<0.1$

${ }^{* *} p<0.5$

\section{Discussion}

This study has found an earnings gap of 4.4 percent between male and female senior university administrators through the first decade of the twenty-first century when accounting for executive position and institutional characteristics, an amount smaller than the 13 percent gap identified by Monks and McGoldrick (2004) in the 1990s and similar to that reported in Essaji and Horton (2010). However, by considering the academic fields and career experience of the administrators, the earnings gap falls to only 2.6 percent and is no longer statistically significant, suggesting that previous studies which have ignored personal characteristics of the administrators have overstated the true earnings gap attributable to gender, in particular because the distribution of males and females across academic fields differs.

The impact of academic field on administrator earnings has not been thoroughly explored in the literature as the three previous studies to consider the characteristic have been limited in scope and focused solely on presidential/vice-chancellor salaries: Bartlett and Sorokina (2005) only examined differences in presidential salaries between business, economics, law, and liberal arts specialists while Baimbridge and Simpson (1996) and Monks (2007), relying on small sample sizes of between 49 and 67 observations could find a statistically significant premium only among sciences specialists compared to humanities and social sciences specialists. This study thus adds to the literature on university administrator earnings 
by expanding the examination of academic fields considered and by examining administrators further down the organizational hierarchy.

The pattern of administrator earnings across academic fields is consistent with studies of faculty earnings (e.g. Brown et al., 2011; Ehrenberg et al., 2006; Toutkoushian, Bellas, \& Moore, 2007; Warman et al., 2010) in which those in professional fields have been shown to earn more than colleagues in liberal fields. Such earnings differentials among faculty are typically justified based on the alternative employment prospects of those in particular professional fields (for example doctors, engineers, lawyers, etc.), and on the differing nature of the work performed - professors of engineering produce new engineers with high average earnings profiles while professors of humanities subjects produce graduates with much lower average earnings profiles (e.g. Boothby and Drewes, 2006).

While 81 percent of administrators examined have come from a career in the academy, they have moved from (potentially) doing very different jobs to doing similar types of work since, for example, the role of a Vice President Academic would be similar whether the incumbent was a biologist, a philosopher, or an engineer. That the distribution of earnings among administrators based on their academic field mirrors the distribution among faculty based on academic field suggests that it is the result of a market differential due to specialists in some fields having greater alternative employment options. As shown in Table 3, the earnings premiums for academic fields completely explain the differences in earnings among most deans, with the exception of deans of business and health science who earn significant premia over all other deans. Possible explanations for why these two types of deanships earn such large premia might include higher tuition revenues in these fields or increased job complexity relative to deans of other disciplines, and it is recommended that these differences relative to other deans be a topic for further study.

While, Binder et al. (2010) have shown that the unequal distribution of males and females across academic fields accounts for part of the gender earnings differential among faculty, the same outcome is evident here; male administrators are more likely than their female counterparts to have specialized in a health science discipline or in engineering, two of the three fields with the highest earnings premiums. As shown in Table 3 , roughly one fifth of the initial gender earnings gap identified can be explained by earnings differences across academic fields.

While differences in bargaining outcomes between males and females have been noted in the literature (Babcock et al., 2006; Babcock \& Laschever, 2003; Small, Gelfand, Babcock, \& Gettman, 2007), the evidence presented here is mixed. One indicator of bargaining in this market, the salary premium negotiated by those hired externally, differs by only 1.6 percent between males and females and that difference is not statistically significant, suggesting that females, as external candidates, may not be disadvantaged in bargaining and may behave in a manner similar to males. However, Table 4 demonstrates that female administrators entering newly created positions earn less than male administrators in newly created positions, indicating that, without the benefit of an incumbent's salary level to use as a benchmark, females are offered and accept lower compensation than their male peers. Furthermore, as shown in Table 3, a one percent increase in revenue corresponds to a 7.4 percent increase in male administrator earnings but a 12.2 percent increase in female administrator earnings, implying that females are more disadvantaged in smaller institutions, a result consistent with studies of the private sector which have shown that the gender earnings gap is larger in smaller firms (Bertrand \& Hallock, 2001; Drolet, 2002a).

From the perspective of achieving gender earnings parity, these results are encouraging. Although previous studies have shown a large significant earnings gap between male and female university administrators across the organizational hierarchy, much of the gap can be accounted for by personal factors other than gender which had not previously been considered, indicating that female administrators are much closer than previously thought to achieving earnings parity with their male colleagues. Nevertheless, earnings inequality among university administrators from different academic fields raises important questions of equity, productivity, and the desirability of pursuing a (second) career as an administrator depending on one's academic interests. That faculty who specialize in different fields, and thus conduct different types of research and produce different types of graduates, have different earnings is well documented; however, whether engineers and lawyers make more productive or otherwise "better" administrators relative to economists and historians, and thus merit higher pay for performing the same job, is clearly a topic which should be explored in greater detail. 


\section{Acknowledgements}

The author would like to thank Prof. Colin P. Green and Prof. Steve Bradley of Lancaster University for their guidance, as well as participants at the 2018 Canadian Economics Association Conference for helpful feedback.

\section{References}

Altonji, J. G., Blom, E., \& Meghir, C. (2012). Heterogeneity in human capital investments: High school curriculum, College Major, and Careers. Annual Review of Economics, 4, 195-223.

Babcock, L., Gelfand, M., Small, D., \& Stayn, H. (2006). Gender differences in the propensity to initiate negotiations. In D. De Crèmer, M. Zeelenberg, \& J. K. Murnighan (Eds.), Social Psychology and Economics. Mahwah, NJ: Lawrence Erlbaum.

Babcock, L., \& Laschever, S. (2003). Women don't ask: Negotiation and the gender divide. Princeton, $\mathrm{NJ}$ : Princeton University Press.

Bailey, S. (1992). Shortchanging girls, Shortchanging America: $A$ call to action. Washington, DC: Women's Educational Foundation, American Association of University Women.

Baimbridge, M., \& Simpson, C. (1996). Rewards to academia: The remuneration of vice chancellors and principals. Applied Economics, 28(6), 631-639.

Bartlett, R. L., \& Sorokina, O. (2005). Determinants of presidential pay at national liberal arts institutions. The Review of Higher Education, 29(1), 53-68.

Bertrand, M., \& Hallock, K. F. (2001). The gender gap in top corporate jobs. Industrial and Labor Relations Review, 55(1), 3-21.

Binder, M., Krause, K., Chermak, J., Thacher, J., \& Gilroy, J. (2010). Same work, different pay? Evidence from a US public university. Feminist Economics, 16(4), 105-135.

Blau, F. D., Ferber, M. A., \& Winkler, A. E. (2002). The economics of women, men and work. Upper Saddle River, NJ: Prentice-Hall.

Blau, F. D., \& Kahn, L. M. (2000). Gender differences in pay. Journal of Economic Perspectives, 14(4), 75-99.
Boothby, D., \& Drewes, T. (2006). Postsecondary education in Canada: Returns to university, college and trades education. Canadian Public Policy, 32(1), 1-21.

Brown, L. K., Troutt, E., \& Prentice, S. (2011). Ten years after: Sex and salaries at a Canadian university. Canadian Public Policy, 37(2), 239-255.

Chevalier, A. (2007). Education, occupation and career expectations: Determinants of the gender pay gap for UK graduates. Oxford Bulletin of Economics and Statistics, 69(6), 819-842.

Chia, G., \& Miller, P. W. (2008). Tertiary performance, field of study and graduate starting salaries. Australian Economic Review, 41(1), 15-31.

Clements, K. W., \& Izan, H. Y. (2008). The stairway to the top: The remuneration of academic executives. Australian Journal of Management, 33(1), 1-30.

Cyrenne, P., \& Grant, H. (2009). University decision making and prestige: An empirical study. Economics of Education Review, 28(2), 237-248.

Doucet, C., Durand, C., \& Smith, M. (2008). Who gets market supplements? Gender differences within a large Canadian university. Canadian Journal of Higher Education, 38(1), 67-103.

Drewes, T. (2006). Returns to college education: Evidence from the 1990, 1995, and 2000 National Graduates Surveys. Ottawa, ON: Human Resources and Social Development Canada.

Drolet, M. (2002a). Can the workplace explain Canadian gender pay differentials? Canadian Public Policy, 28(supplement), S41-S63.

Drolet, M. (2002b). New evidence on gender pay differentials: Does measurement matter? Canadian Public Policy, 28(1), 1-16.

Eckel, C. C., \& Grossman, P. J. (2002). Sex differences and statistical stereotyping in attitudes towards financial risk. Evolution and Human Behavior, 23(4), 281-295.

Ehrenberg, R. G., Cheslock, J. L., \& Epifantseva, J. (2001). Paying our presidents: What do trustees value? The Review of Higher Education, 25(1), 15-37. 
Ehrenberg, R G., McGraw, M., \& Mrdjenovic, J. (2006). Why do field differentials in average faculty salaries vary across universities? Economics of Education Review, 25(3), 241-248.

Essaji, A., \& Horton, S. (2010). Silent escalation: Salaries of senior university administrators in Ontario, 1996-2006. Higher Education, 59(3), 303-322.

Flory, J. A., Leibbrandt, A., \& List, J. A. (2014). Do competitive work places deter female workers? A large-scale natural field experiment on job-entry decisions. The Review of Economic Studies, 82(1), 122-155.

Furnham, A., \& Wilson, E. (2011). Gender differences in estimated salaries: A UK study. The Journal of Socio-Economics, 40(5), 623-630.

Gayle, G-L., Golan, L., \& Miller, R. A. (2012). Gender differences in executive compensation and job mobility. Journal of Labor Economics, 30(4), 829-871.

Ginther, D. K., \& Hayes, K. J. (2003). Gender differences in salary and promotion for faculty in the humanities 1977-95. Journal of Human Resources, 38(1), 34-73.

Gneezy, U., Niederle, M., \& Rustichini, A. (2003). Performance in competitive environments: gender differences. Quarterly Journal of Economics, 118(3), 1049-1074.

Goldin, C., \& Rouse, C. (2000). Orchestrating impartiality: The impact of 'blind' auditions on female musicians. American Economic Review, 90(4), 715-741.

Greenman, E., \& Xie, Y. (2008). Double jeopardy? The interaction of gender and race on earnings in the United States. Social Forces, 86(3), 1217-1244.

Gunderson, M. (1989). Male-female wage differentials and policy responses. Journal of Economic Literature, 27(1), 46-72.

Gunderson, M. (2006). Viewpoint: Male-female wage differentials: how can that be? Canadian Journal of Economics, 39(1), 1-21.

Hansen, J. (2006). Returns to university level education: Variations within disciplines, occupations and employment sectors. Ottawa, ON: Human Resources and Social Development Canada.
Holzer, H., \& Neumark, D. (2000). Assessing affirmative action. Journal of Economic Literature, 38(3), 483-568.

Huang, Y. S., \& Chen, C. R. (2013). Are college chief executives paid like corporate CEOs or bureaucrats? Applied Economics, 45(21), 3035-3043.

Jalbert, T., Furumo, K., \& Jalbert, M. (2011). Does Educational Background Affect CEO Compensation And Firm Performance? The Journal of Applied Business Research, 27(1), 15-39.

Jarrell, S. B., \& Stanley, T. D. (2004). Declining bias and gender wage discrimination? A meta-regression analysis. Journal of Human Resources, 39(3), 828-838.

Langbert, M., \& Fox, M. (2013). The compensation and benefits of private university presidents. Journal of Academic Administration in Higher Education, 9(2), 45-56.

Le, A. T., Miller, P. W., Slutske, W. S., \& Martin, N. G. (2011). Attitudes towards economic risk and the gender pay gap. Labour Economics, 18(4), 555-561.

Livanos, I., \& Pouliakas, K. (2012). Educational segregation and the gender wage gap in Greece. Journal of Economic Studies, 39(5-6), 554-575.

McCormick, A., Nunez, A. M., Shah, V., \& Choy, S.P. (1999). Life after college: A descriptive summary of 1992-93 bachelor's degree recipients in 1997. Washington, DC: U.S. Government Printing Office.

Mcdowell, J. M., \& Kiholm Smith, J. (1992). The effect of gender-sorting on propensity to coauthor: implications for academic promotion. Economic Inquiry, 30(1), 68-82.

Mendleson, R. (2012, January 2). CEO compensation in Canada jumped 27 per cent in 2010, CCPA says. Huffington Post. Retrieved from: http://www.huffingtonpost.ca/2012/01/02/ceo-compensation-canada-jumps-27-percent n 1180168.html

Mishel, L., \& Sabadish, N. (2013). CEO pay in 2012 was extraordinarily high relative to typical workers and other high earners. Washington, DC: Economic Policy Institute.

Monks, J. (2007). Public versus private university 
presidents pay levels and structure. Economics of Education Review, 26(3), 338-348.

Monks, J., \& Ehrenberg, R. (1999). U.S News \& World Report college rankings: Why do they matter? Change, 31(6), 42-51.

Monks, J., \& McGoldrick, K. (2004). Gender earnings differentials among college administrators. Industrial Relations, 43(4), 742-758.

Napari, S. (2011). University major and the gender wage gap. Empirical Economics Letters, 10(2), 145-154.

Need, A., \& de Jong, U. (2008). Personality traits and gender-specific income expectations in Dutch higher education. Social Indicators Research, 86(1), 113-128.

Niederle, M., \& Vesterlund, L. (2007). Do women shy away from competition? Do men compete too much?. The Quarterly Journal of Economics, 122(3), 1067-1101.

Ornstein, M., Stewart, P., \& Drakich, J. (2007). Promotion at Canadian universities: The intersection of gender, discipline, and institution. Canadian Journal of Higher Education, 37(3), 1-25.

Palia, D. (2000). The impact of regulation on ceo labor markets. RAND Journal of Economics, 31(1), 165-179.

Pfeffer, J., \& Davis-Blake, A. (1987). Understanding organizational wage structures: A resource dependence approach. Academy of Management Journal, 30(3), 437-455.

Pfeffer, J., \& Ross, J. (1988). The compensation of college and university presidents. Research in Higher Education, 29(1), 79-91.

Powell, M., \& Ansic, D. (1997). Gender differences in risk behaviour in financial decision-making: an experimental analysis. Journal of Economic Psychology, 18(6), 605-628.

Purcell, K., Elias, P., Davies, R., \& Wilton, N. (2005). The class of '99: A study of the early labour market experience of recent graduates. Warwick, UK: Warwick Institute for Employment Research.

Schubert, R., Brown, M., Gysler, M., \& Brachinger, H. W.
(1999). Financial decision-making: are women really more risk averse? American Economic Review, 89(2), 381-385.

Small, D. A., Gelfand, M., Babcock, L., \& Gettman, H. (2007). Who goes to the bargaining table? The influence of gender and framing on the initiation of negotiation. Journal of Personality and Social Psychology, 93(4), 600-613.

Soh, L. H. C. (2007). The market for australian vice-chancellors. Australian Journal of Management, 32(1), 29-55.

Tang, T. L-P., Tang, D. S-H., \& Tang, C. S-Y. (2000). Factors related to university presidents' pay: An examination of private colleges and universities. Higher Education, 39(4), 393-415.

Toutkoushian, R. K., Bellas M. L., \& Moore, J. V. (2007). The Interaction Effects of Gender, Race, and Marital Status on Faculty Salaries. Journal of Higher Education, 78(5), 572-601.

U.S. Department of Education (2005). Gender differences in participation and completion of undergraduate education and how they have changed over time. Washington, DC: U.S. Government Printing Office.

Warman, C., Woolley, F., \& Worswick, C. (2010). The evolution of male-female earnings differentials in Canadian universities, 1970-2001. Canadian Journal of Economics, 43(1), 347-372.

Wijesingha, R., \& Ramos, H. (2017). Human capital or cultural taxation: What accounts for differences in tenure and promotion of racialized and female faculty? Canadian Journal of Higher Education, 47(3), 54-75.

Williams, M. J., Levy Paluck, E., \& Spencer-Rodgers, J. (2010). The masculinity of money: Automatic stereotypes predict gender differences in estimated salaries. Psychology of Women Quarterly, 34(1), 7-20.

\section{Contact Information}

Colin Mang

cmang@wlu.ca 


\section{Notes}

1 An exception is made for administrators who did not proceed directly from undergraduate to graduate studies, with the years spent between degrees included in total estimated work experience.

\section{Appendix}

Determinants of Earnings for Associate and Assistant Vice Presidents by Career Background

\begin{tabular}{|c|c|c|c|}
\hline & $\begin{array}{l}\text { I } \\
\text { Academic Career }\end{array}$ & $\begin{array}{l}\text { II } \\
\text { Professional Career }\end{array}$ & $\begin{array}{l}\text { III } \\
\chi^{2} \text {-test of academic-profes- } \\
\text { sional differences }\end{array}$ \\
\hline Female & $\begin{array}{l}0.034 \\
(0.043)\end{array}$ & $\begin{array}{l}-0.040 \\
(0.031)\end{array}$ & 2.13 \\
\hline Business & $\begin{array}{l}0.079^{* *} \\
(0.036)\end{array}$ & $\begin{array}{l}0.031 \\
(0.034)\end{array}$ & 1.03 \\
\hline Economics & $\begin{array}{l}-0.018 \\
(0.040)\end{array}$ & & \\
\hline Education & $\begin{array}{l}0.023 \\
(0.060)\end{array}$ & $\begin{array}{l}0.086 \\
(0.102)\end{array}$ & 0.30 \\
\hline Engineering & $\begin{array}{l}0.119^{* *} \\
(0.047)\end{array}$ & $\begin{array}{l}-0.046 \\
(0.064)\end{array}$ & $4.72^{* *}$ \\
\hline Law & $\begin{array}{l}0.010 \\
(0.038)\end{array}$ & $\begin{array}{l}0.058^{*} \\
(0.034)\end{array}$ & 0.96 \\
\hline Health science & $\begin{array}{l}0.145 \\
(0.134)\end{array}$ & & \\
\hline Nursing & $\begin{array}{l}0.017 \\
(0.106)\end{array}$ & & \\
\hline Sciences & $\begin{array}{l}0.076^{* *} \\
(0.034)\end{array}$ & $\begin{array}{l}-0.024 \\
(0.092)\end{array}$ & 1.12 \\
\hline Social science & $\begin{array}{l}0.070 \\
(0.049)\end{array}$ & $\begin{array}{l}0.029 \\
(0.044)\end{array}$ & 0.41 \\
\hline Social work & $\begin{array}{l}0.121^{* * *} \\
(0.042)\end{array}$ & $\begin{array}{l}0.095^{* *} \\
(0.041)\end{array}$ & 0.21 \\
\hline Experience (years) & $\begin{array}{l}0.005^{* *} \\
(0.002)\end{array}$ & $\begin{array}{l}0.005^{* * *} \\
(0.002)\end{array}$ & 0.01 \\
\hline Position Tenure (years) & $\begin{array}{l}0.004 \\
(0.003)\end{array}$ & $\begin{array}{l}0.003 \\
(0.004)\end{array}$ & 0.00 \\
\hline Associate Professor & $\begin{array}{l}-0.094^{* *} \\
(0.036)\end{array}$ & & \\
\hline
\end{tabular}




\begin{tabular}{llll}
\hline & I & II & III \\
& Academic Career & Professional Career & $\begin{array}{l}\chi^{2} \text {-test of academic-profes- } \\
\text { sional differences }\end{array}$ \\
\hline External Hire & $0.210^{* * *}$ & 0.026 & $11.38^{* * *}$ \\
Associate VP & $(0.048)$ & $(0.031)$ & 2.51 \\
Revenue (log) & 0.046 & -0.032 & \\
& $(0.044)$ & $(0.026)$ & 0.43 \\
Institutional Characteristics & $0.082^{* * *}$ & $0.104^{* * *}$ & \\
Time Effects & $(0.024)$ & $(0.025)$ & \\
Reference Case (Constant) & Included & Included & \\
& Included & Included & \\
& $(0.429)$ & $10.175^{* * *}$ & \\
Observations & & $(0.330)$ & \\
Clusters & 439 & 339 & \\
$R^{2}$ & 113 & 87 & \\
\hline
\end{tabular}

${ }^{\mathrm{e}}$ - An individual who holds (has held) a tenured or tenure-track academic appointment

f - An individual who has not pursued a career in the academy, i.e. has not previously held a tenured or tenure-track appointment

$\mathrm{g}$ - Reference case represents the log salary for an individual with the following characteristics when all continuous variables in Equation 1 are set at zero (i.e. the constant term in Equation 1).

Column I: A male assistant vice president with an academic specialization in the humanities who holds an academic appointment as a professor and who is promoted internally

Column II: A male assistant vice president with an academic specialization in the humanities and who is promoted internally

${ }^{*} p<0.1$

${ }^{* *} p<0.5$

${ }^{* * *} p<0.01$ 